\title{
Usefulness of the Korean Knee Score for Evaluation of the Results of Total Knee Arthroplasty
}

\author{
Jin Kyu Lee, MD, Ji-Hoon Shim, MD, Kyu-Sung Chung, MD, and Choong Hyeok Choi, MD \\ Department of Orthopedic Surgery, Hanyang University College of Medicine, Seoul, Korea
}

\begin{abstract}
Purpose: The Korean Knee score (KKS) was designed to reflect the floor-sitting lifestyle that necessitates high knee flexion. The purpose of this study is to assess whether the KKS reflects the floor-sitting lifestyle more accurately than the previously developed Knee Society clinical rating system. In addition, the presence of ceiling effects was compared between the two rating systems.

Materials and Methods: Eighty-one consecutive patients (120 knees) who were assessed regularly after total knee arthroplasty (TKA) on an outpatient basis between January 2012 and December 2012 were enrolled. All patients were asked to complete a questionnaire to assess the Knee Society Knee score (KSKS), Knee Society Function score (KSFS), and KKS.

Results: At the final follow-up, the mean KSKS, KSFS, and KKS were 91.2, 86.0, and 70.1, respectively, and the scores were similar between the $\geq 125^{\circ}$ maximum flexion group and $<125^{\circ}$ maximum flexion group. However, the 'floor life' subdomain score of the KKS was significantly higher in the $>125^{\circ}$ maximum flexion group ( 15.13 vs. $11.24, \mathrm{p}=0.001$ ). The number of cases with the highest possible score was 24 (20\%) for the KSKS and 47 (39\%) for the KSFS, whereas none of the cases obtained the highest possible KKS. According to the standard deviation method, more substantial ceiling effects were present in the KSKS (83 cases, 69.1\%) and KSFS (67 cases, 55.8\%) than in the KKS (23 cases, 19.2\%).

Conclusions: Although, the KKS was effective in reducing the ceiling effect, it demonstrated limited improvement in assessing the ability to perform high knee flexion after TKA. However, the 'floor life' subdomain of KSS appeared to be valid for evaluating high flexion of the knee.
\end{abstract}

Keywords: Knee, Arthroplasty, Korean knee score, Ceiling effect, High flexion, Floor life

\section{Introduction}

Total knee arthroplasty (TKA) has been recognized as a successful surgical procedure for the treatment of knee arthritis refractory to conservative therapy. Although TKA has been associated with favorable objective outcomes and high patient satisfaction ${ }^{1)}$, efforts have been continuously made to improve objectivity in the clinical assessment of postoperative results by developing multiple scoring systems. Such systems assign a point value for each

Received March 20, 2014; Revised June 30, 2014;

Accepted July 7, 2014

Correspondence to: Choong Hyeok Choi, MD

Department of Orthopedic Surgery, Hanyang University College of Medicine, 222 Wangsimni-ro, Seongdong-gu, Seoul 133-792, Korea Tel: +82-2-2290-8483, Fax: +82-2-2299-3774

E-mail: chhchoi@hanyang.ac.kr

This is an Open Access article distributed under the terms of the Creative Commons Attribution Non-Commercial License (http://creativecommons.org/licenses/by-nc/3.0/) which permits unrestricted non-commercial use, distribution, and reproduction in any medium, provided the original work is properly cited. assessment item, mainly pain, range of motion, joint stability, deformity, and joint contracture, for preoperative and postoperative evaluation in TKA patients ${ }^{2,3)}$. However, various studies have suggested that there is some discrepancy between the clinical results obtained by scoring systems and patient's satisfaction and functional outcome ${ }^{4)}$. In particular, the presence of ceiling effects in some scoring systems may affect their reliability as valid evaluation tools ${ }^{5)}$.

The Knee Society Knee score (KSKS) and Knee Society Function score (KSFS) are most commonly used for the assessment of the knee joint; however, they may not be reliable for the assessment of the ability to perform high flexion in Korean patients who are expected to sit on the floor more often than westerners. Patients with limited range of flexion have difficulty in sitting cross-legged on the floor or standing up from sitting position on the floor. Ueo et al. ${ }^{6}$ suggested $\geq 120^{\circ}$ of flexion should be achieved to resume the floor-sitting lifestyle after TKA. Choi et al. ${ }^{7)}$ reported that the most common complaints among Korean patients after TKA were the difficulty of standing up from the 
Table 1. Korean Knee Score

\begin{tabular}{|c|c|c|c|c|c|}
\hline \multirow{2}{*}{ 1. Pain \& symptoms } & \multicolumn{5}{|c|}{ Scores $(4-0)$} \\
\hline & & & & & \\
\hline 1) Pain during sleep & $\square$ None & $\square$ Mild & $\square$ Moderate & $\square$ Severe & $\square$ Extrem \\
\hline 2) Pain on sitting or lying & $\square$ None & $\square$ Mild & $\square$ Moderate & $\square$ Severe & $\square$ Extrem \\
\hline 3) Pain on standing & $\square$ None & $\square$ Mild & $\square$ Moderate & $\square$ Severe & $\square$ Extrem \\
\hline 4) Pain on stair climbing & $\square$ None & $\square$ Mild & $\square$ Moderate & $\square$ Severe & $\square$ Extrem \\
\hline 5) Pain during walking & $\square$ None & $\square$ Mild & $\square$ Moderate & $\square$ Severe & $\square$ Extrem \\
\hline 6) Morning stiffness & $\square$ None & $\square$ Mild & $\square$ Moderate & $\square$ Severe & $\square$ Extrem \\
\hline 7) Afternoon stiffness on sitting, lying, and resting & $\square$ None & $\square$ Mild & $\square$ Moderate & $\square$ Severe & $\square$ Extreme \\
\hline 8) Pain on maximum knee flexion & $\square$ None & $\square$ Mild & $\square$ Moderate & $\square$ Severe & $\square$ Extreme \\
\hline 9) Knee swelling & $\square$ Never & $\square$ Rarely & $\square$ Sometimes & $\square$ Often & $\square$ Always \\
\hline 10) Pain on maximum knee extension & $\square$ None & $\square$ Mild & $\square$ Moderate & $\square$ Severe & $\square$ Extreme \\
\hline 11) Grinding, clicking, or other noise from the knee & $\square$ Never & $\square$ Rarely & $\square$ Sometimes & $\square$ Often & $\square$ Always \\
\hline 12) Locking (inability to bend or straighten the knee) & $\square$ Never & $\square$ Rarely & $\square$ Sometimes & $\square$ Often & $\square$ Always \\
\hline \multicolumn{6}{|l|}{ 2. Function } \\
\hline $\begin{array}{l}\text { 13) Difficulty performing heavy household chores } \\
\text { (e.g. house cleaning, maintenance, heavy laundry) }\end{array}$ & $\square$ None & $\square$ Mild & $\square$ Moderate & $\square$ Severe & $\square$ Extreme \\
\hline 14) Difficulty in getting on/off a vehicle & $\square$ None & $\square$ Mild & $\square$ Moderate & $\square$ Severe & $\square$ Extreme \\
\hline 15) Difficulty in descending stairs & $\square$ None & $\square$ Mild & $\square$ Moderate & $\square$ Severe & $\square$ Extrem \\
\hline 16) Difficulty in ascending stairs & $\square$ None & $\square$ Mild & $\square$ Moderate & $\square$ Severe & $\square$ Extreme \\
\hline $\begin{array}{l}\text { 17) Difficulty performing light household chores } \\
\text { (e.g. light house cleaning, dishwashing, laundry) }\end{array}$ & $\square$ None & $\square$ Mild & $\square$ Moderate & $\square$ Severe & $\square$ Extreme \\
\hline 18) Difficulty in rising from sitting & $\square$ None & $\square$ Mild & $\square$ Moderate & $\square$ Severe & $\square$ Extrem \\
\hline 19) Difficulty performing grocery shopping & $\square$ None & $\square$ Mild & $\square$ Moderate & $\square$ Severe & $\square$ Extrem \\
\hline 20) Difficulty in bending down & $\square$ None & $\square$ Mild & $\square$ Moderate & $\square$ Severe & $\square$ Extrem \\
\hline 21) Difficulty in standing & $\square$ None & $\square$ Mild & $\square$ Moderate & $\square$ Severe & $\square$ Extreme \\
\hline 22) Difficulty in walking & $\square$ None & $\square$ Mild & $\square$ Moderate & $\square$ Severe & $\square$ Extrem \\
\hline 23) Difficulty in getting on/off toilet & $\square$ None & $\square$ Mild & $\square$ Moderate & $\square$ Severe & $\square$ Extreme \\
\hline 24) Difficulty in getting in and out of bath & $\square$ None & $\square$ Mild & $\square$ Moderate & $\square$ Severe & $\square$ Extrem \\
\hline 25) Difficulty in rising from bed & $\square$ None & $\square$ Mild & $\square$ Moderate & $\square$ Severe & $\square$ Extrem \\
\hline 26) Difficulty in lying in bed & $\square$ None & $\square$ Mild & $\square$ Moderate & $\square$ Severe & $\square$ Extrem \\
\hline 27) Difficulty in putting on socks or pantyhose & $\square$ None & $\square$ Mild & $\square$ Moderate & $\square$ Severe & $\square$ Extrem \\
\hline 28) Difficulty in taking off socks or pantyhose & $\square$ None & $\square$ Mild & $\square$ Moderate & $\square$ Severe & $\square$ Extrem \\
\hline 29) Difficulty in sitting on a chair & $\square$ None & $\square$ Mild & $\square$ Moderate & $\square$ Severe & $\square$ Extrem \\
\hline \multicolumn{6}{|l|}{ 3. Evaluation of floor life } \\
\hline 30) Pain on kneeling (e.g. for bowing or praying) & $\square$ None & $\square$ Mild & $\square$ Moderate & $\square$ Severe & $\square$ Extrem \\
\hline 31) Pain on squatting & $\square$ None & $\square$ Mild & $\square$ Moderate & $\square$ Severe & $\square$ Extreme \\
\hline 32) Pain on making a bed on the floor & $\square$ None & $\square$ Mild & $\square$ Moderate & $\square$ Severe & $\square$ Extrem \\
\hline 33) Pain on sitting with crossed legs & $\square$ None & $\square$ Mild & $\square$ Moderate & $\square$ Severe & $\square$ Extrem \\
\hline 34) Pain on squatting with legs crossed & $\square$ None & $\square$ Mild & $\square$ Moderate & $\square$ Severe & $\square$ Extrem \\
\hline 35) Pain on rising from a low chair & $\square$ None & $\square$ Mild & $\square$ Moderate & $\square$ Severe & $\square$ Extrem \\
\hline \multicolumn{6}{|l|}{ 4. Socio-emotional function } \\
\hline 36) Efforts at lifestyle modification to avoid knee straining activities & $\square$ None & $\square$ Mild & $\square$ Moderate & $\square$ Severe & $\square$ Extrem \\
\hline 37) General discomfort in the knee & $\square$ None & $\square$ Mild & $\square$ Moderate & $\square$ Severe & $\square$ Extrem \\
\hline $\begin{array}{l}\text { 38) Difficulty with social relationships (with family members, friends, and } \\
\text { neighbors) due to physical or emotional reasons in the past one month }\end{array}$ & $\square$ None & $\square$ Mild & $\square$ Moderate & $\square$ Severe & $\square$ Extreme \\
\hline 39) Reluctance to travel due to the knee & $\square$ None & $\square$ Mild & $\square$ Moderate & $\square$ Severe & $\square$ Extreme \\
\hline \multirow[t]{2}{*}{ 40) Frequency of awareness of the knee joint problem } & $\square$ Never & \multicolumn{2}{|c|}{$\square$ Once per month } & \multicolumn{2}{|c|}{$\square$ Once per week } \\
\hline & $\square$ Once $\mathrm{p}$ & er day & $\square$ Always & & \\
\hline 41) Difficulty due to lack of confidence in the knee & $\square$ None & $\square$ Mild & $\square$ Moderate & $\square$ Severe & $\square$ Extreme \\
\hline
\end{tabular}


floor which often requires the support of the hands and insufficient range of high flexion. In an attempt to overcome the limitations of the KSKS and KSFS in assessing Korean TKA patients with the floor-sitting lifestyle, the Korean Knee Society devised the Korean Knee score (KKS) system designed to accommodate the evaluation of high flexion after TKA in 2009. Ha et al. ${ }^{8)}$ described it as an effective scoring system with high specificity and sensitivity.

The purpose of this study is to investigate whether the KKS system is useful for evaluating the ability to perform high flexion after TKA and reducing the ceiling effect compared to the KSKS and KSFS.

\section{Materials and Methods}

Of the patients who underwent outpatient evaluation after TKA between January 2012 and December 2012, those who were available for a minimum 1-year follow-up were retrospectively reviewed. The patients were asked to complete a questionnaire during an outpatient visit. The exclusion criteria were suspected postoperative infection and cognitive inability to understand the questionnaire. The total number of patients was 81 (male: 4, female: 77; 120 knees) with a mean age of 69 years (range, 51 to 86 years). The operated side was the right side in 64 knees and the left side in 56 knees. The preoperative diagnosis was degenerative osteoarthritis in 106 knees and rheumatoid arthritis in 14 knees. The surgery was bilateral in 39 patients and unilateral in 42 patients. The mean follow-up period was 33 months (range, 13 to 65 months). In all knees, a posterior cruciate ligament substituting implant was used: Scorpio NRG (Stryker, Mahwah, NJ, USA) in 42 knees; NexGen LPS (Zimmer Inc., Warsaw, IN, USA) in 46 knees; PFC Sigma (Johnson \& Johnson, Raynham, MA, USA) in 21 knees; and Optetrak (Exactech Inc., Gainesville, FL, USA) in 11 knees.

Postoperative assessments were performed using the clinical rating system of the American Knee Society (KSKS and KSFS) and the KKS ${ }^{3,8}$. The American Knee Society clinical rating system consists of the knee score and function score and the scores range from 0 to 100 points. The KSKS evaluates pain, range of knee motion, stability, flexion contracture, extension lag, and alignment, whereas the KSFS evaluates walking distance, stair climbing ability, and use of walking aid.

The KKS is composed of four 4 subdomains (41 items): 1) pain and symptoms (12 items); 2) function (17 items); 3) evaluation of floor life (6 items); and 4) socio-emotional function (6 items). Each item can be scored up to 4 points and the total score is con- verted to a 100-point scale for evaluation (Table 1).

The presence of a ceiling effect was determined according to the method of McHorney and Tarlov ${ }^{9)}(\geq 15 \%$ of the patients scored the highest possible points) and the standard deviation method ${ }^{10)}$ (the proportion of cases with points greater than the highest possible point minus the value of standard deviation) and the percentages of cases that meet both definitions of ceiling effect were calculated for each scoring system. Histograms and scatter plots were used for the analysis of score distributions. The Kolmogorov-Smirnov test was used to evaluate the null hypothesis that the assessment results would follow a normal distribution.

Considering that the knee with $\geq 125^{\circ}$ of flexion is awarded the highest possible point on the range of flexion assessment in the American Knee Society clinical rating system, we divided the patients into those with $\geq 125^{\circ}$ of maximum range of flexion (high flexion group) and those with $<125^{\circ}$ of maximum range of flexion (non-high flexion group) and investigated intergroup differences in the KSKS, KSFS, and KKS. In addition, the high flexion group and the non-high flexion group were compared with regard to the scores for four subdomains of the KKS system.

Statistical analysis was performed using the SAS ver. 9.2 (SAS Institute Inc., Cary, NC, USA). The Wilcoxon rank sum test was used with the statistical significance set at $\mathrm{p}<0.05$.

\section{Results}

In the total 120 knees, the mean KSKS was 91.2 points (range, 50 to 100 points), the mean KSFS was 86.0 points (range, 30 to 100 points), and the mean KKS was 70.1 points (range, 25 to 99 points) (Table 2).

On the ceiling effect analysis, the percentage of knees with the highest possible KSKS was 24 knees (20\%) and that with the highest possible KSFS was 47 knees (39\%), indicating the presence of ceiling effects for the two scoring systems. On the other hand, there was no case with the highest possible score for the KKS. However, when assessed according to the standard devia-

Table 2. Comparison of Various Scoring Systems Included in the Study

\begin{tabular}{ccccc}
\hline \multicolumn{2}{c}{ Variable } & \multicolumn{1}{c}{ KSKS } & \multicolumn{1}{c}{ KSFS } & KKS \\
\hline ROM $\left({ }^{\circ}\right) \quad \geq 125(\mathrm{n}=90)$ & $91.7 \pm 9.2$ & $85.5 \pm 16.4$ & $70.7 \pm 15.5$ \\
& $<125(\mathrm{n}=30)$ & $89.7 \pm 10.4$ & $84.7 \pm 12.2$ & $68.5 \pm 16.9$ \\
Total $(\mathrm{n}=120)$ & $91.2 \pm 9.5$ & $86.0 \pm 15.3$ & $70.1 \pm 15.7$ \\
\hline
\end{tabular}

Values are presented as mean \pm standard deviation.

KSKS: Knee Society Knee score, KSFS: Knee Society Function score, KKS: Korean Knee score, ROM: range of motion. 
tion method, profound ceiling effects were observed: in 83 knees (69.1\%) for the KSKS, 67 knees (55.8\%) for the KSFS, and 23 knees (19.2\%) for the KKS (Table 3).

The histogram of the distribution of points for the three different scoring systems showed a normal distribution curve for the KKS, whereas the curve was skewed to the right (negatively skewed distribution) for the KSKS and KSFS (Fig. 1).

Table 3. Ceiling Effects of Each Scoring System

\begin{tabular}{ccc}
\hline \multirow{2}{*}{ Scoring system } & \multicolumn{2}{c}{ Method } \\
\cline { 2 - 3 } & McHorney and Tarlove & Standard deviation ${ }^{10)}$ \\
\hline KSKS & $20(24)$ & $69.1(83)$ \\
KSFS & $39(47)$ & $55.8(67)$ \\
KKS & $0(0)$ & $19.2(23)$ \\
\hline
\end{tabular}

Values are presented as percentage (number).

KSKS: Knee Society Knee score, KSFS: Knee Society Function score, KKS: Korean Knee score.
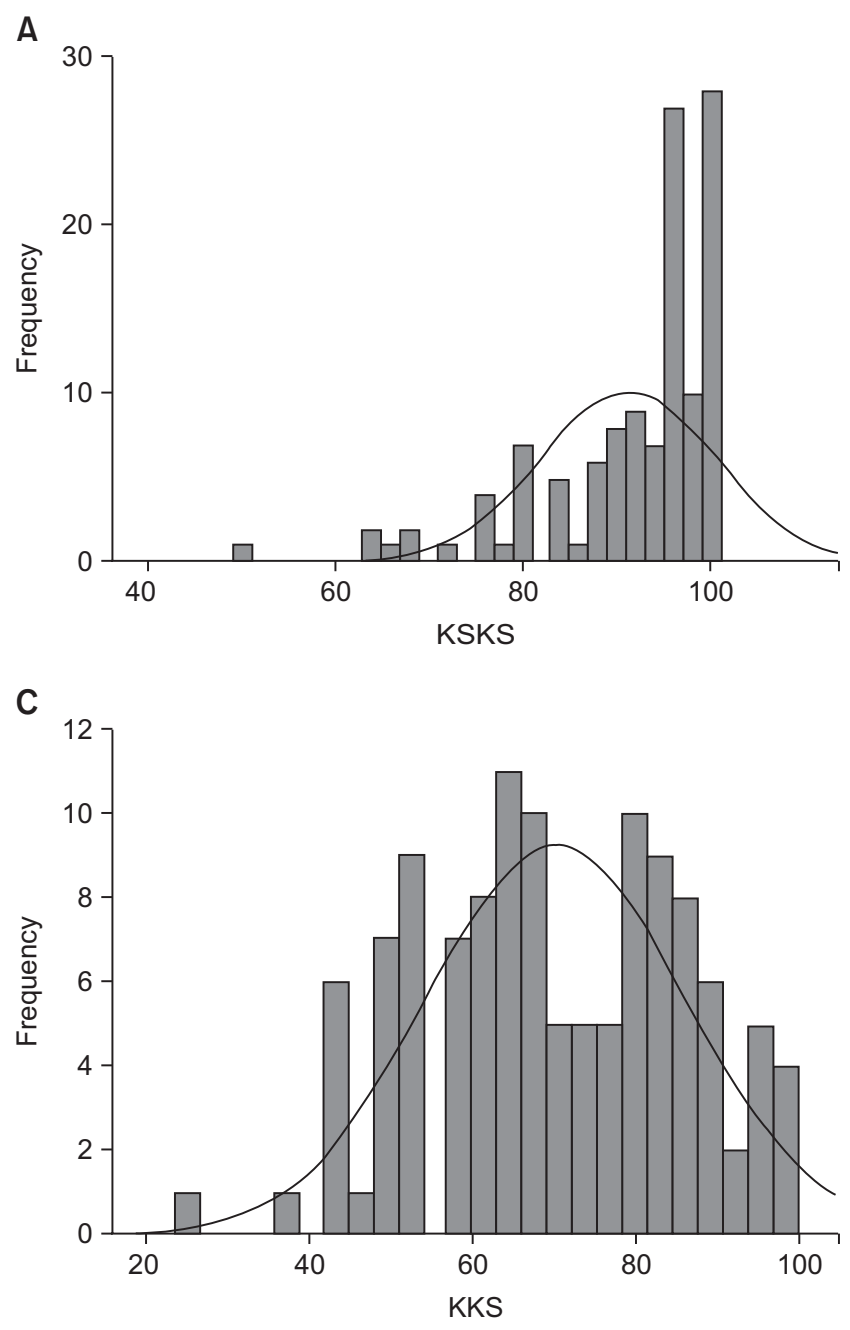

There was no notable change in the shape of the distribution for each scoring system when the patients were subdivided into two groups according to the maximum knee flexion (Fig. 2).

On the Kolmogorov-Smirnov test for normal distribution, the null hypothesis was rejected for the KSKS and KSFS ( $p<0.001)$, and thus the two scoring systems were not found to follow a normal distribution. The KKS was found to conform to a normal distribution ( $\mathrm{p}=0.087)$.

In the 90 knees with $\geq 125^{\circ}$ maximum knee flexion, the mean KSKS was 91.7 points (range, 50 to 100 points), the mean KSFS was 85.5 points (range, 30 to 100 points), and the mean KKS was 70.7 points (range, 38 to 99 points). In the 30 knees with $<125^{\circ}$ maximum knee flexion, the mean KSKS was 89.7 points (range, 64 to 95 points), the mean KSFS was 84.7 points (range, 60 to 100 points), and the mean KKS was 68.5 points (range, 25 to 97 points). There was no statistically significant intergroup difference with regard to the KSKS ( $\mathrm{p}=0.310)$ KSFS ( $\mathrm{p}=0.541)$, and KKS (p=0.496) (Table 4).

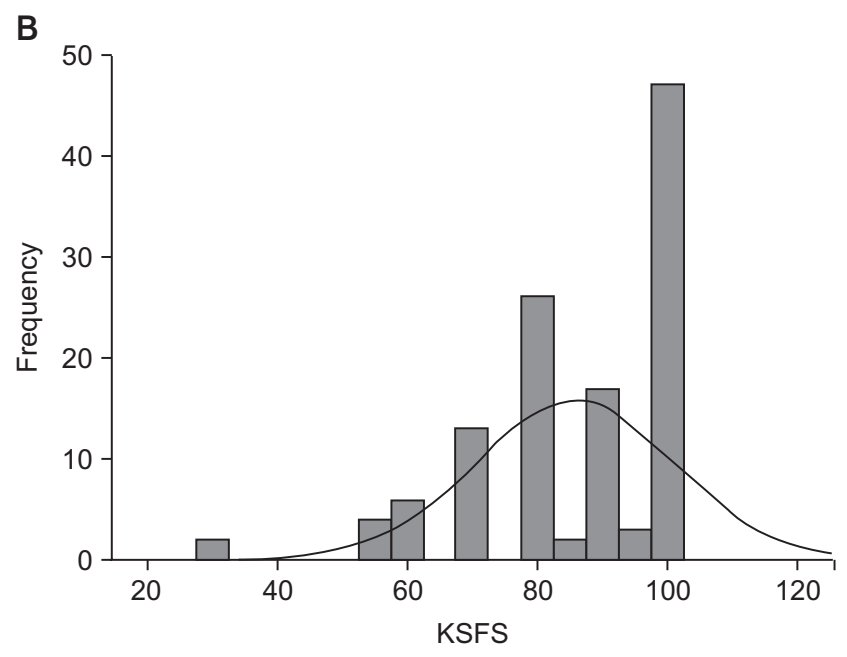

Fig. 1. Frequency distribution of the Knee Society Knee score (KSKS) (A), Knee Society Function score (KSFS) (B), and Korean Knee score (KKS) (C). 

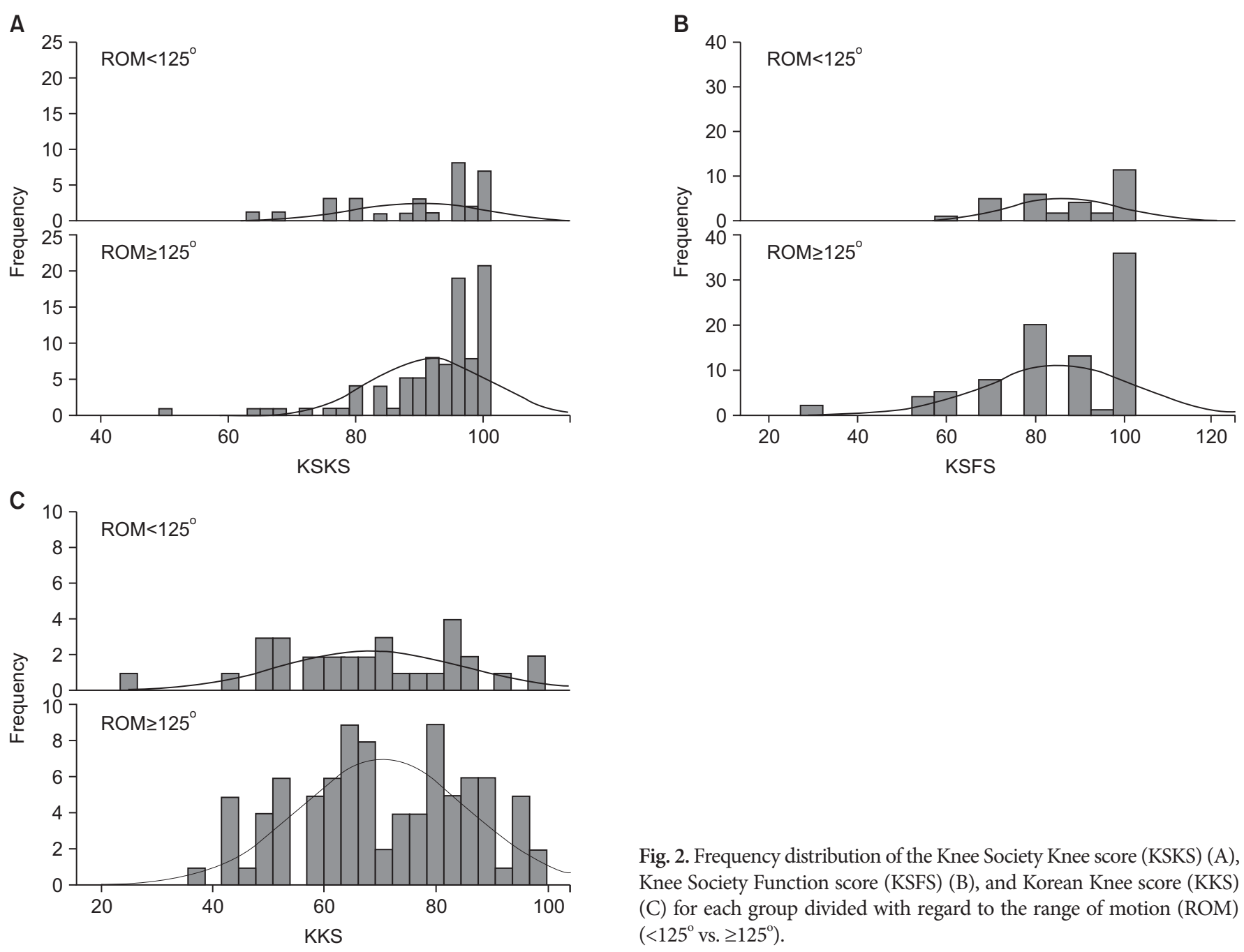

Fig. 2. Frequency distribution of the Knee Society Knee score (KSKS) (A), Knee Society Function score (KSFS) (B), and Korean Knee score (KKS) (C) for each group divided with regard to the range of motion (ROM) $\left(<125^{\circ}\right.$ vs. $\left.\geq 125^{\circ}\right)$.

Table 4. Analysis of Each Scoring System in Regard to Range of Motion (ROM)

\begin{tabular}{cccc}
\hline \multirow{2}{*}{ Scoring system } & \multicolumn{2}{c}{$\operatorname{ROM}\left({ }^{\circ}\right)$} & p-value \\
\cline { 2 - 3 } & $\geq 125(\mathrm{n}=90)$ & $<125(\mathrm{n}=30)$ & \\
\hline KSKS & $91.7 \pm 9.2$ & $89.7 \pm 10.4$ & 0.310 \\
KSFS & $85.5 \pm 16.4$ & $84.7 \pm 12.2$ & 0.541 \\
KKS & $70.7 \pm 15.5$ & $68.5 \pm 16.9$ & 0.496 \\
\hline
\end{tabular}

Values are presented as mean \pm standard deviation.

KSKS: Knee Society Knee score, KSFS: Knee Society Function score, KKS: Korean Knee score.

The scatter plots for the comparison of the KSKS and KKS and the KSFS and KKS displayed a wide distribution pattern for the KKS system, as opposed to those of the KSKS and KSFS where the majority of points were concentrated in the upper-right corner, indicating the presence of ceiling effects (Fig. 3).

Regarding the subdomains of the KKS system, no statistically significant difference between the high flexion group $(n=90)$ and the non-high flexion group $(n=30)$ was observed in the evaluation of pain and symptoms (mean value, 36.2 points vs. 38.2 points; $\mathrm{p}=0.238$ ), function (mean value, 50.3 points vs. 51.4 points; $\mathrm{p}=0.835$ ), and socio-emotional function (mean value, 16.5 points vs. 15.9 points; $\mathrm{p}=0.624$ ) except for the floor life evaluation (mean value, 15.1 points vs. 11.2 points; $\mathrm{p}=0.001$ ) (Table 5).

\section{Discussion}

TKA provides satisfactory outcomes in terms of pain relief and functional improvement, especially in patients with degenerative osteoarthritis or rheumatoid arthritis of the knee. Studies have shown that recent TKA implants offer superior longevity of minimum 20 years and demonstrate remarkable efficacy ${ }^{11-14)}$. Currently, various scoring systems are available for the assessment of postoperative clinical outcomes. Of those, the KSKS and KSFS 

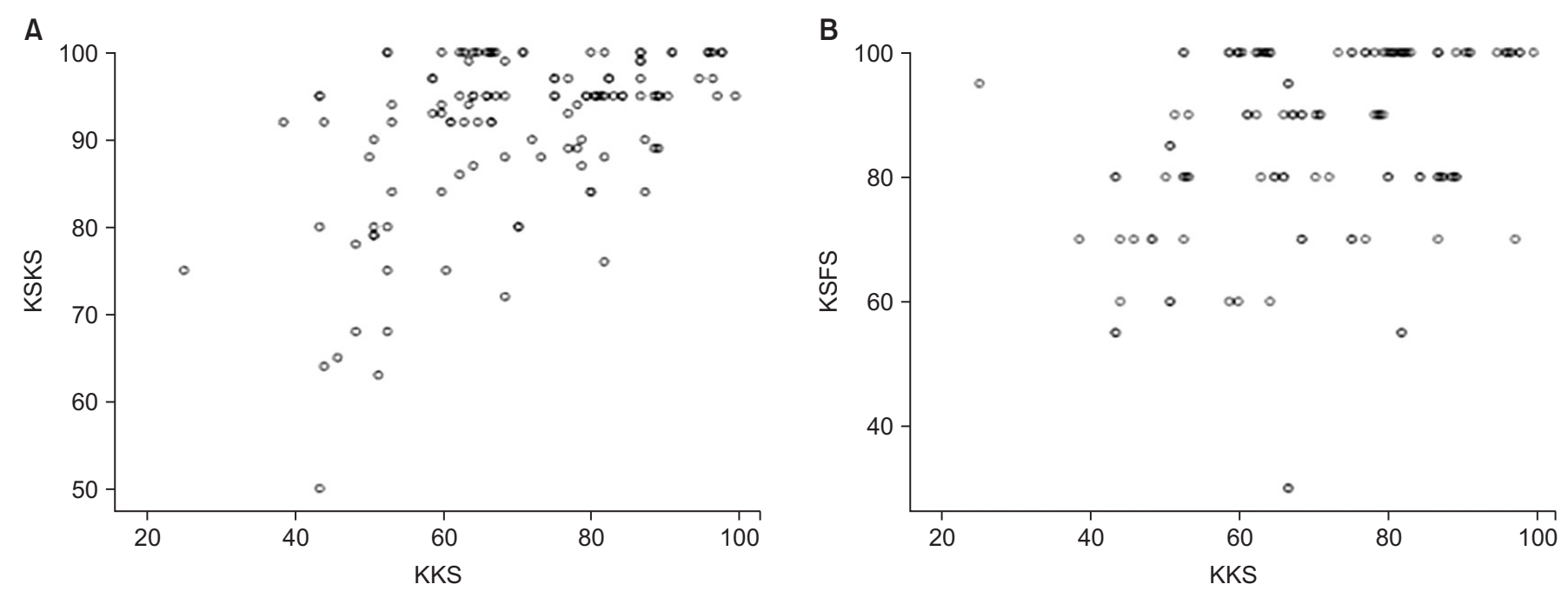

Fig. 3. Scatter plots of the Korean Knee score (KKS) vs. Knee Society Knee score (KSKS) (A) and the Korean Knee score vs. Knee Society Function score (KSFS) (B) showing the ceiling effects of the KSKS and KSFS.

Table 5. Analysis of Each Assessment Category of Korean Knee Score (KKS) in Regard to Range of Motion (ROM)

\begin{tabular}{lccc}
\hline \multirow{2}{*}{ Assessment category (range) } & \multicolumn{2}{c}{ ROM $\left(^{\circ}\right)$} & p-value \\
\cline { 2 - 3 } & $\geq 125(\mathrm{n}=90)$ & $<125(\mathrm{n}=30)$ & 0.001 \\
\hline Evaluation of floor life (0-24) & $15.1 \pm 5.5$ & $11.2 \pm 5.9$ & 0.238 \\
Pain and symptom (0-48) & $36.2 \pm 8.1$ & $38.2 \pm 7.4$ & 0.835 \\
Function (0-68) & $50.3 \pm 13.3$ & $51.4 \pm 10.9$ & 0.502 \\
Socio-emotional function (0-24) & $16.5 \pm 4.7$ & $15.9 \pm 4.5$ & \\
\hline
\end{tabular}

Values are presented as mean \pm standard deviation.

have been preferred by orthopedic surgeons and employed in research since Insall et al. ${ }^{3)}$ introduced the clinical rating system.

The outcomes of TKA are assessed with respect to pain, range of motion, knee function, and joint abnormality on radiography. Of these, objective parameters, such as range of motion, joint stability, and radiographic alignment, are of particular interest to orthopedic surgeons, whereas patients are more concerned about function and tend to make more subjective assessments, which results in some disagreement in the evaluation of treatment outcomes. However, the focus of postoperative assessment has recently been shifted from joint abnormality to functional improvement. In this respect, the patient-derived KKS system can be more useful than the physician-derived KSKS and KSFS systems. Lingard et al. ${ }^{15}$ ) suggested that the Western Ontario and McMaster Universities Arthritis Index and Short Form-36 could be more effective than the KSKS and KSFS in the assessment of TKA outcomes. Likewise, the efficacy of KSKS and KSFS has been questioned by some research. In particular, it has been noted that the clinical rating system exhibits ceiling effects: it does not reflect subjective and functional discomfort experienced during sitting on the floor or standing up from the sitting position by patients from countries where high flexion position is often unavoidable due to the floor-sitting lifestyle ${ }^{4}$. In the current study, the KKS demonstrated less ceiling effects than the KSKS and KSFS; therefore, we believe that the KKS would be useful for eliminating ceiling effects. On the other hand, there was no statistically significant difference in the KKS between the high flexion group and the non-high flexion group. It is our understanding that the KKS may not be effective in reflecting the level of activities demanding high flexion. However, on the assessment of the KKS subdomains, a significant intergroup difference was observed in the floor life evaluation. Thus, we believe that the floor life subdomain of the KKS can be used as a predictor of postoperative knee flexion. Although we suggest that the accuracy of postoperative evaluation can be improved by using scores for each subdomain separately than using the sum of the scores for all subdomains, this should be verified in further studies involving larger study populations. 
The limitations of this study are the following: 1) selection bias could have occurred by including the outpatient clinic cases only; 2) the influence of the degree of improvement and preoperative status on the outcome was not addressed due to the lack of comparison between the preoperative and postoperative KSKS, KSFS, and KKS; and 3) $125^{\circ}$ knee flexion was used as the reference standard for high flexion, which we thought appropriate considering that the highest possible point is awarded for the knee with $\geq 125^{\circ}$ flexion according to the KSKS.

\section{Conclusions}

The KKS was effective in eliminating ceiling effects that occur at high rates for the KSKS and KSFS of the clinical rating system. However, it demonstrated limited efficacy in reflecting the postoperative level of activity when the sum of the scores for all subdomains were used for evaluation. Considering that the floor life evaluation subdomain was useful in assessing the ability to perform high flexion, we recommend using scores for each subdomain separately to improve the evaluation accuracy.

\section{Conflict of Interest}

No potential conflict of interest relevant to this article was reported.

\section{References}

1. Chung HK, Choi CH, Kim JH, Kim SI. Total knee rephacement arthroplasty in rheumatoid arthritis: mid-term followup. J Korean Knee Soc. 2001;13:8-14.

2. Bellamy N, Buchanan WW, Goldsmith CH, Campbell J, Stitt LW. Validation study of WOMAC: a health status instrument for measuring clinically important patient relevant outcomes to antirheumatic drug therapy in patients with osteoarthritis of the hip or knee. J Rheumatol. 1988;15:1833-40.

3. Insall JN, Dorr LD, Scott RD, Scott WN. Rationale of the Knee Society clinical rating system. Clin Orthop Relat Res. 1989;(248):13-4.

4. Kane RL, Maciejewski M, Finch M. The relationship of patient satisfaction with care and clinical outcomes. Med Care. 1997;35:714-30.
5. Na SE, Ha CW, Lee CH. A new high-flexion knee scoring system to eliminate the ceiling effect. Clin Orthop Relat Res. 2012;470:584-93.

6. Ueo T, Kihara Y, Ikeda N, Kawai J, Nakamura K, Hirokawa S. Deep flexion-oriented bisurface-type knee joint and its tibial rotation that attributes its high performance of flexion. J Arthroplasty. 2011;26:476-82.

7. Choi CH, Kim KW, Sung IH, Park YS. Patient satisfaction interviews after TKA successful rehabilitation achieved and functions still desired by respondents. J Korean Knee Soc. 2006;18:20-5.

8. Ha JK, Kim JG, Lee MC, Wang JH; Research Committee for Development of a Novel Knee Evaluation System of Korean Knee Society. What symptoms are more important for Korean patients in knee osteoarthritis? Development and validation of the Korean knee score. Knee Surg Relat Res. 2012;24: 151-7.

9. McHorney CA, Tarlov AR. Individual-patient monitoring in clinical practice: are available health status surveys adequate? Qual Life Res. 1995;4:293-307.

10. Koedel C, Betts J. Value-added to what? How a ceiling in the testing instrument influences value-added estimation. Educ Finance Policy. 2010;5:54-81.

11. Gill GS, Joshi AB, Mills DM. Total condylar knee arthroplasty: 16- to 21-year results. Clin Orthop Relat Res. 1999;(367): 210-5.

12. Keating EM, Meding JB, Faris PM, Ritter MA. Long-term followup of nonmodular total knee replacements. Clin Orthop Relat Res. 2002;(404):34-9.

13. Pavone V, Boettner F, Fickert S, Sculco TP. Total condylar knee arthroplasty: a long-term followup. Clin Orthop Relat Res. 2001;(388):18-25.

14. Ranawat CS, Flynn WF Jr, Saddler S, Hansraj KK, Maynard MJ. Long-term results of the total condylar knee arthroplasty: a 15-year survivorship study. Clin Orthop Relat Res. 1993;(286):94-102.

15. Lingard EA, Katz JN, Wright RJ, Wright EA, Sledge CB; Kinemax Outcomes Group. Validity and responsiveness of the Knee Society Clinical Rating System in comparison with the SF-36 and WOMAC. J Bone Joint Surg Am. 2001; 83:1856-64. 